\title{
PERSUASION IN ENGLISH MOTIVATIONAL DISCOURSE
}

\section{Melko Kh. B.}

\section{INTRODUCTION}

The issue of manipulation of speech is one of the leading modern linguistic studies. There are many approaches to the study of speech influence, which is explained by the complexity and complex nature of this phenomenon. Theory of speech influence was studied by E. Tarasov, A. Baranov, I. Sternin, O. Issers, V. Rizun, A. Danilova, V. Chernyavskaya, E. Shelestyuk.

Speech influence theory, as a science of effective communication, originates in ancient rhetoric, which taught speakers to speak publicly, to debate, and to win discussions. Ancient rhetoric relied on logical rules of thought and belief. The spread of democracy, the development of mass communication, and socio-economic development have become catalysts for the need for new means of persuasion, using not only the logic of reasoning but also the application of psychological and emotional influence on the listener. From the point of view of modern linguistic research, language serves not only as a means of transmitting information, but also influences the interlocutor, thereby regulating personal relationships, mental state and behavior. That is why the issue of speech influence has become the object of research not only in linguistics, but also in a number of related sciences psycholinguistics, sociolinguistics, pragmalinguistics, psychology, rhetoric.

Broadly speaking, speech influence is any speech communication taken in terms of its target conditionality, it is verbal communication described from the position of one of the communicants when he views himself as the subject of influence and his interlocutor as the object. In a narrow sense, verbal influence is used in the field of so-called coordinating relations of equal co-operation, not of subordination relations (formal or informal).

Speech influence on consciousness may be carried out in two forms, explicit and implicit. The main type of impact on open public consciousness is a rhetorical expression. Rhetorical expression is based on the logical principles of constructing the text of the utterance, the ability to argue, to debate, to convince listeners. One of the most effective types of hidden influence is language manipulation. 
The interest in persuasiveness is rooted in ancient rhetoric and is revived in neo-rhetoric, as well as in linguistic pragmatics, which means that these issues are organically incorporated into the modern research paradigm of linguistics, in which linguistic communication is interpreted as a special kind of activity, and social goals in the field of knowledge of the world, the formation of thoughts and beliefs, the regulation of human interaction. Reproducibility of textual persuasiveness is most often studied in the context of emotionality and emotionality of translation.

\section{The study of persuasiveness in modern linguistics}

Mechanisms of influence in various situations of cognition of the world are directed mainly at the formation of thoughts and beliefs, modeling of social and individual behavior. These processes led to the introduction of a new communicative form of influence, a perceptual one, which is an important component of any influence; carries out the process of influence by means of evidence and argument, involving the emotional potential of expression ${ }^{1}$.

Persuasiveness, or persuasion, is a conscious influence on the recipient's assessment of the facts of the surrounding reality and the actions of the recipient's acquaintance with these facts through an appeal to his or her ability to critically comprehend the relevant facts ${ }^{2}$. The basis of belief is the presentation of facts in the context of their relationship with the conclusions, subordinate to the solution of a single functional problem, namely, "the conscious acceptance of a system of judgments and judgments by a person according to another point of view" ${ }^{3}$.

Persuasiveness is interpreted differently by linguists. In the first case, identity is identified with the speaker's objective assessment of the authenticity or unreliability, expression of confidence or uncertainty in the message, or as a reflection of the author on his or someone else's message from the position of the reliability or unreliability of the message information. Otherwise, personality is interpreted as a set of techniques and tools aimed at reinforcing arguments. Ye. Shelestyuk considers persuasiveness a subcategory of argumentativeness, which involves the use of additional rhetorical and sophistic techniques and tools that

\footnotetext{
2016. $250 \mathrm{c}$.

${ }^{2}$ Инжечик А. А. Персуазивная функция языковых средств немецкого политического дискурса // Молодой ученый. 2016. № 9. С. 1270-1275.

${ }^{3}$ Шелестюк Е. В. Способы, типы, приемы и инструменты речевого воздействия // Классическое лингвистическое образование в современном мульти культурном пространстве: материалы междунар. науч. конф.: в 2 ч. Ч. 2. 2006. С. 153-164.
}

${ }^{1}$ Борисова С. С. Персуазивные стратегии в аналитических жанрах медиатекста. Дисс. Орел, 
contribute to persuasion. V. Chernyavskaya considers perjury as the influence of the author of verbal or written communication on his addressee for the purpose of persuading him, to induce or not to take certain actions ${ }^{4}$.

The concept of persuasiveness existed in ancient times. The word "persuasiveness" comes from the Latin persudeo (-sus, -susum, -re), which means to persuade, to assure, to induce, to incline, to persuade. To be able to convince, persuade listeners to adopt favorable for the speaker's point of view it was very important to ancient orator, indeed, for any social or political figure throughout history ${ }^{5}$.

Persuasion, following the logic of Cicero and Aristotle, contains a basic persuasive formula that consists of such components as enhancing knowledge, building confidence, stimulating desire, emphasizing need, and seeking an answer ${ }^{6}$. However, researchers began to actively show scientific interest in this category only in the middle of the twentieth century, against the background of intensive development of psychology and theories related to border disciplines, for example, psycholinguistics and cognitive linguistics. In fact, today it can be argued that in the field of humanitarian knowledge, persuasive rhetoric is a methodology of persuasion. It is assumed that the function of persuasion and intention in social practice is performed by language and speech ${ }^{7}$.

The analysis of the scientific literature devoted to the problems of persuasiveness allows us to objectively distinguish between two directions that have emerged in the study of this phenomenon: psychological and linguistically oriented. The phenomena of language and speech, which are described with the help of this concept, have been studied in the framework of stylistics, linguistics of the text, psycholinguistics, cognitive linguistics, theories of linguistic action, theory of argumentation. ${ }^{8}$

The term "persuasiveness" has various interpretations in national and English linguistics. In the first sense, this concept is considered in the context of linguistics of the text as an assessment by the speaker of the

${ }^{4}$ Дейк Т.А. ван. Язык. Познание. Коммуникация / пер. с англ.; сост. В. В. Петрова; под ред. В. И. Герасимова; вступ. ст. Ю. Н. Караулова, В. В. Петрова. Москва: Прогресс, 1989. 312 с.

${ }^{5}$ Голоднов А. В. Риторический метадискурс: основания прагмалингвистического моделирования и социокультурной реализации (на материале современного немецкого языка). Санкт-Петербург: Астерион, 2011. 344 с.

${ }^{6}$ Rank H. Persuasion analysis: A companion to composition. Park Forest: Counter-Propaganda Press, 1988. $160 \mathrm{p}$.

${ }^{7}$ Харджиева Е. С. Персуазивность в детективно-следственном дискурсе (на материале романов Н. И. Леонова и А. В. Макеева). Дис. Ростов-на-Дону, 2016. 165 с.

${ }^{8}$ Скрябіна В. Б. Персуазивні стратегії любовного дискурсу: комунікативно-прагматичний аспект (на матеріалі англійськомовної художньої прози XX століття). Дис. Київ, 2011. Автореферат. 20 с. 
objective content of the sentence by its veracity and unreliability, the expression of confident or uncertain knowledge, or as a reflection of the author on his or someone else's message from the standpoint of true or false information ${ }^{9}$ According to this approach, it is not about the objective possibility / impossibility of the speaker, but about the subjective confidence / uncertainty of the speaker in his / her probability ${ }^{10}$.

Persuasiveness expresses the degree of linguistic knowledge of connections and relationships of reality; it is subjective in that it is always linked to the speaker's conclusions. This is an externally syntactic category of modus, which is mostly expressed by syntagmatically isolated elements - modal words, particles, modal phrases. It is a modality of communication, not action, characterizing all judgments as a whole, not a way of detecting the relation between an object and a sign ${ }^{11}$.

Persuasiveness is also interpreted, more in keeping with the intrinsic form of this English word, as a form of manipulation that opposes rational reasoning, or as a set of techniques and means aimed at reinforcing arguments in the process of argumentation. In modern linguistics, persuasiveness is understood as "a communicative-speaking strategy aimed at rational persuasion and emotional influence on the addressee in order to induce him to commit certain post-communicative actions"12. A. Golodnov considers perceptual communication to be one of the forms of influence on human behavior, and in the most general form defines it as "mental-speech interaction of communicants, which realizes the attempt of influence of the addressee on the mental sphere of the recipient in order to change his behavior (urging to exercise / refuse certain postcommunicative actions)" ${ }^{\text {13 }}$.

According to V. Skryabina, persuasive communication as a special form of realization of the mental and speech activity of the addressee aims at convincing the addressee of the need to make a decision on the implementation of certain actions in the interests of the addressee. In persuasive communication, the process of persuasion, aimed at accepting

\footnotetext{
${ }^{9}$ Шелестюк Е. В. Текстовые категории аргументативности, суггестивности и императивности как отражение способов речевого воздействия // Вестник Челябинского государственного университета (Серия «Филология. Искусствоведение»). 2008. Вып. 26. № 30 (131). С. 170-175.

${ }^{10}$ Баган М. Заперечення як засіб увиразнення персуазивних значень // Проблеми гуманітарних наук. 2011. № 28. С. 108-116.

${ }_{11}^{11}$ Шинкарук В. Д. Модус і диктум у структурі речення. Дис. Київ, 2003. Автореферат. 31 с.

12 Клименская Е. А. Персуазивный потенциал нативной рекламы в интернет-издании Meduza // Конференция «Ломоносов 2018». URL: https://omonosov-msu.ru/archive/Lomonosov_2018/data/13260/ 78100_uid245654_report.pdf.

${ }^{13}$ Голоднов А. В. Лингвопрагматические особенности персуазивной коммуникации (на примере современой немецкоязычной рекламы). Дисс. Санкт-Петербург, 2003. Автореферат. 23 с.
} 
the addressee's rational argument, interacts with the process of persuasion ("seduction"), which enhances the argumentation and influences the emotional sphere of the addressee, appeals to his feelings ${ }^{14}$.

The term "persuasiveness" can take on a negative connotation, since the concept of the same name refers to the notion of manipulation, as well as the use of certain linguistic means to influence the thought and behavior of the recipient. A negative tone may also arise because a direct perceptual action implies a change (in the expected direction) of the thought process in the mind of the reader with further perlocutionary effect. According to scientists, the negative orientation of the term "persuasiveness" remains questionable. One can only state unequivocally the fact that persuasiveness focuses on the influential potential of the text ${ }^{15}$.

In a broad sense, persuasiveness in linguistics, or more precisely, pragmalinguistics, is understood as the deliberate influence of the addressee on the addressee in order to persuade him of something, to induce him to commit or refrain from committing certain actions. There are two communicative and pragmatic intentions of persuasiveness: the influence of linguistic means on the addressee, in his opinion, and the evaluation and the prompting of him to commit certain actions, one way or another, related to the change and direction of his behavior ${ }^{16}$.

There are two communicative-pragmatic intentions when performing a speech act:

1) to influence the addressee's consciousness, his thoughts, evaluations;

2) to induce him to take certain actions, to change his behavior.

There are two ways to realize these intentions:

1) intellectually, that is, through rational arguments;

2) affective, based on imagination, on subjective - emotional evaluations, stereotypes ${ }^{17}$.

Persuasive influence implies the attainment of the desired goal through the conviction based on rational justification, not excluding, but on the contrary, assuming and taking into account the emotional and evaluative means of influence, the subjective factors. In these texts,

${ }^{14}$ Скрябіна В. Б. Персуазивний портрет перекладача // Науковий вісник кафедри Юнеско КНЛУ Серія Філологія. 2014. № 28. С. 59-64. 2016. $250 \mathrm{c}$

15 Борисова С. С. Персуазивные стратегии в аналитических жанрах медиатекста. Дисс. Орел,

${ }^{16}$ Харджиева Е. С. Персуазивность в детективно-следственном дискурсе (на материале романов Н. И. Леонова и А. В. Макеева). Дис. Ростов-на-Дону, 2016. 165 с.

${ }^{17}$ Смирнова И. В. Использование языковых средств речевой манипуляции для реализации персуазивной стратегии в текстах программ испанских политических партий // Вестник Российского университета Дружбы народов. Серия: Вопросы образования. Языки и специальность. 2014. № 2. С. 78-84. 
speakers use a wide range of perceptual means: presenting their own opinion on a problem, evaluating or judging a topic, reinforcing arguments, demonstrating a problem in a positive or negative light, indicating likelihood, confidence or commitment, stimulating audience emotions, directing emotions actions. To enhance the perlocutionary effects of persuasion, technologies such as:

1) special highlighting of the topic and aggravation of the approach to the problem under discussion, choosing a specific perspective of its consideration;

2) concretization, that is, the avoidance of abstractions and the deliberate choice of detail to the detriment of the general;

3) simplification, in other words, the presentation of complex reality in a reduced or adapted form for the needs of the recipient;

4) polarization as a reference to opposites;

5) intensification as a focus on conflict rather than consensus;

6) personification, that is, attribution and characterization of events from the perspective of the producer of information ${ }^{18}$.

A. Inzhechik identifies several levels of pervasive communication, on which there are specific means of persuasion:

1) at the content-compositional level, the following compositional components have a pervasive influence:

- numerical indicators and statistics allow to draw the attention of the recipient to the problem or event, to give credibility and authenticity to the words;

- a quote as part of actively functioning way of illustration, argumentation and attract attention. Quoting allows you to switch attention to the language of facts, dates and figures to a live human speech;

- references to documents, reputable sources reduce the critical perception of information and have some convincing potential;

2) at the communicative-strategic level different communication tactics are used:

- valuable renaming tactics are the most significant tactics. The renamed class is subjected to a comparative class, which is assigned a certain grade;

- tactics of attribution of the object of positive evaluative characteristics. The verbalization of evaluations is realized by: general-

18 Правикова Л. В. Персуазивность как когнитивная стратегия в парламентском дискурсе // Филологические науки. Вопросы теории и практики. 2018. № 1(79). Ч. 2. С. 359-362. 
value predicates with abstract-positive value (good, fair, right) or partialvalue predicates that express either a mostly rational or predominantly emotional evaluation;

- the tactic of absolutizing the evaluation implies the location of certain characteristics in the maximum range of the rating scale;

- appeal tactics for stereotypically positive / negative values are aimed at including the object of evaluation in the system of positive / negative evaluation;

- tactics of creating a problem situation helps to solve a foreseeable or real problem situation or one that is "imposed" on the recipient;

- "appeal to authority" tactics are appeals to a single or group authoritative thought: the thoughts of a celebrity, specialist, organization, research institute, etc ${ }^{19}$.

For the implementation of the persuasive function of language in the practical activity of mankind has developed an extensive system of means of speech expression, represented primarily by paths and figures, "linguistic gestures", which are intended to optimize communication and provide a high degree of influence of the text on the recipient ${ }^{20}$.

Persuasiveness strategies and tactics are reflected in the linguistic layout of the text. Persuasiveness in the following texts operates at all linguistic levels:

1) At the lexical level, the most important point is choosing the right verbal content. The persuasive texts are well-prepared to promote the speaker's ideas and plans in order to gain audience approval and support. It is important to choose a topic that is urgent and important for society at some stage in its development. Accordingly, depending on the topic, the audience, the situation of communication and the choice of vocabulary, and therefore the lexical means of expression of persuasiveness: frequent use of the same words, compound words, formal and informal forms of language. For American discourse, the frequent use of words such as faith, hope, love, courage, which appeals to overcoming difficulties and seeking support in this, is inherent. I travel the world encouraging millions of people to overcome adversity with faith, hope, love, and courage so that they may pursue their dreams;

2) at the grammatical level, the types of sentences, their length, structure, the use of tenses and ways of the verb, the use of personal

\footnotetext{
${ }^{19}$ Petty R. E., Cacioppo J. T. Communication and Persuasion. Central and Peripheral Routs to Attitude Change. New York: Springer, 1986. 262 p.

20 Лобода Ю. А. Відтворення експресивних засобів політичних промов українською мовою (на матеріалі публічних виступів політиків Великої Британії та США). Дис. Київ, 2011. Автореферат. 21 с.
} 
pronouns, repetitions, exclamations, vocatives, rhetorical questions are the means of expressing persuasiveness. Together, the possibilities for us are just ridiculous. So what do you say? Shall we give it a go, mate?

3 ) at the stylistic level, the use of literary techniques is characteristic of per- sonal communication. Therefore, the creative approach of speakers to the use of language, which would distinguish their speeches from others, is an integral part of the process of creating a pervasive discourse. Authors of persuasive texts try to find their own style, in harmony with their image and personality, which would allow to establish communication with the audience in the most favorable way for them. Even still, once I chilled out (quite literally), my quality of life received a big boost from my newly freed toes.

The most important point in a personalized message is its coherence, a kind of invisible thread that connects all discourse. Grammatical and lexical cohesion are also important, but coherence is crucial for a successful understanding of the persuasive texts and the appeal that they contain, because it makes them integral, acquires a logical development of events, which in turn contributes to the function of persuasion ${ }^{21}$.

The assessment of the communicant's situation as perceptual is based on the coincidence of the parameters of this situation with the prototypical characteristics of perceptual communication, which include, first of all, the real or simulated equality of the addressee and the recipient, both in social and communicative aspect, thus making the recipient's decision / failure to act in the interests of the addressee. In this case, in a persuasive communicative situation, it is obligatory to have real or foreseeable differences between the communicants regarding the necessity / desirability / possibility of the recipient to execute the postcommunicative actions that the addressee tries to eliminate by implementing his or her persuasive intention, to convince the actions / conditions.

If the parameters of a particular communicative situation are in line with the parameters of the prototype persuasive situation, the addressee (consciously or unconsciously) chooses the linguistic macroactivity of the persuasiveness as a means of potentially successful realization of his pragmatic intention, and the recipient ascribes the addressee's statements [4].

Thus, persuasiveness in work is defined as a communicative-speech strategy aimed at rational persuasion and emotional influence on the

${ }^{21}$ Стецик Т.С. Система лінгвістичних засобів вираження персуазивності в політичному дискурсі. URL: https://naub.oa.edu.ua/2013/systema-linhvistychnyh-zasobiv-vyrazhennya-persuazyvnosti-vpolitychnomu-dyskursi/. 
addressee in order to induce him to commit certain post-communicative actions; accordingly, persuasive communication is a special form of realization of the mental and speech activity of the addressee with the purpose of convincing the addressee that it is necessary to make a decision on the implementation of certain actions in the interests of the addressee. Participants in persuasive communication use a wide range of persuasive means both at the logical level (emphasis on a particular issue, concretization, simplification, polarization, intensification, etc.), and at the linguistic level (lexical, grammatical and stylistic linguistic means of persuasion). Persuasive communication implies that there are some differences between the communicants, which it aims to overcome by influencing one of such communicators on the other.

\section{Motivational discourse as a sample of persuasive discourse}

The second half of the twentieth century was characterized by an increase in the attention of linguists to the study of discourse. The origins of discourse theory should be found in studies of language (P. Hartmann's German School), in sociolinguistic analysis of communication (American school E. Scheglov, R. Zachs), in modeling language generation, in describing the ethnography of communication, and in anthropological studies (A. Greymas ) ${ }^{22}$. The term "discourse" is used in various meanings, enabling scientists to argue for the "blur" of its conceptual boundaries. In particular, the concept of discourse is associated with images of communication in society (communicative discourse) ${ }^{23}$ and communication within certain channels (visual discourse). In addition, discourse is associated with the manifestation of rules of communication, ways of presentation and implementation of the pragmatic goal of speakers (didactic discourse). Discourse is also seen as a manifestation of cultural communication. For example, the discourse of modernism is distinguished. There is an intercultural discourse given the ethnocultural features of communication. The social, age, and gender characteristics of the communication participants are also identified with the types of

\footnotetext{
${ }^{22}$ Кучик Г. Б. Структурно-семантичні та дискурсивні особливості англійськомовних текстів установчих документів міжнародних організацій. Дис. Львів, 2016. 244 с.

23 Лютянська Н. І. Відтворення ситуацій міжетнічної взаємодії у мас-медійних британських та американських дискурсивних практиках. Дис. Миколаїв, 2017. 219 с.
} 
discourse. In such cases, they speak, in particular, of political discourse $e^{24}$ and feminist discourse ${ }^{25}$.

The existence of a considerable number of discourse concepts has influenced the emergence of a number of interpretations of it, but there is still no single clear definition that would reflect all the multifaceted nature of this phenomenon in general scientific categories ${ }^{26}$. Given the diversity of interpretations of the term "discourse" there is its definition as "a type of communicative activity, an interactive phenomenon, a speech stream that has different forms of expression, occurs within a specific channel of communication, regulated by the strategies and tactics of participants" ${ }^{27}$.

A characteristic feature of the development of discourse at the present stage of linguistics is the integration of communicative and activity lines of research. Within the active approach, according to which it is a means of ensuring social activity linguistic identity discourse is seen as a social construction of reality and form of expression of knowledge. $\mathrm{N}$. Arutyunova defines the discourse as "a cohesive text in conjunction with extralinguistic, pragmatic, sociocultural, psychological and other factors; the text, taken in the event aspect ... Discourse is a language "immersed in life". Discourse is "not just linguistic / speech formation, more complex than a single sentence, but a total cultural phenomenon: the result and factor of communication, the interweaving of linguistic interactions of communication agents, a living medium of communication, which is known to create new physical actions, mental and mental products ${ }^{28}$. In view of this, different types of discourse are distinguished, including scientific, political, economic, mass media and, in particular, motivational discourse.

"Motive" is one of the basic psychological categories, and the category of motive corresponds to reality as "a system of specific subjectoriented energy-dynamic relations of the subject with the reality, given by the interaction of natural and socio-cultural principles in his mental organization". Motivation is the set of all determinants of behavior,

\footnotetext{
${ }^{24}$ Славова Л. Л. Мовна особистість у сучасному американському та українському політичному дискурсі. Дис. Київ, 2015. Автореферат. 36 с.

25 Приходько Н. Ю. Феминистский дискурс мировых религий: статус женщины в буддийской традиции // Вестник ТГЭУ. Серия: Философия. 2009. № 4. С. 95-104.

${ }^{26}$ Іванців О. В. Когнітивно-дискурсивні основи формування корпоративного іміджу (на матеріалі англійськомовних прес-релізів міжнародних косметичних компаній). Дис. Львів, 2015. 225 с.

27 Бацевич Ф.С. Основи комунікативної лінгвістики: 2-ге вид., доп. Київ: ВЦ «Академія», 2009. $376 \mathrm{c}$.

${ }^{28}$ Арутюнова Н. Д. Дискурс // Лингвистический энциклопедический словарь. Москва: Советская энциклопедия, 1990. С. 137.
} 
internal and external (incentives, needs, ideals, values, etc.). This is a kind of generic term to refer to all the dynamic and vector variables that determine human behavior ${ }^{29}$.

The scientific theory of motivation is a whole construction of the interwar period - 20-30-ies of XX century and links its development (in the US) to certain socio-economic processes of the time: the popularization of psychoanalysis and its global excursion into the problems of causing human behavior (respectively, competition and the desire of official science to have a priority in this field), education (awareness) opportunities for students to lose their desire to learn and the lack of adequate explanations), the emergence of vocational guidance (and involvement of psychologists through it), the involvement of psychologists in solving advertising problems (for example, opening in 1925 that is the most effective advertising, which creates a "new willingness") request industry to solve problems unwillingness to work and job satisfaction (due to the lack of results from the simple reward and punishment) ${ }^{30}$.

Motivational discourse is understood by V. Klimchuk as "a set of texts with motivational constructions, which are in the field of reading of an individual, have a clear target and exist within other discursive genres (mainly political, marketing and educational)", as "fragment of a holistic socio-cultural discourse in the who constructs the motivational discourses of the individual”. According to J. Podolyak, motivational discourse is "verbal interaction between the addressee and the addressee in order to have a positive influence on the emotional, volitional and activity sphere of the latter" ${ }^{31}$. Like other types of discourse, motivational discourse has a set of characteristics that require comprehensive study.

The particular importance of motivational discourse for the modern English-speaking society can be confirmed by the presence of separate oral and written genres that perform a motivating function. The oral genres of English-language motivational discourse include, for example, "commencement speech" - sidewalk speeches at a graduation ceremony, "pep talk" - a coach's pre-match speech, "keynote speech" - a famous person's corporate speech at a corporate event, as well as sermons. Writing

29 Климчук В.О. Мотиваційний дискурс особистості: на шляху до соціальної психології мотивації: монографія. Житомир: Вид-во ЖДУ ім. І. Франка, 2015. 290 с.

${ }^{30}$ Климчук В. О. Мотиваційний дискурс особистості в інтеракційному просторі. Дис. Київ, 2015. Автореферат. 20 c.

31 Подоляк Ж. И. К вопросу о выделении мотивационного дискурса // Электронный научнопрактический журнал «Гуманитарные научные исследования». URL: http://human.snauka.ru/2016/05/14850. 
genres are represented by numerous motivational books. A characteristic feature of motivational discourse is the presence of a creolized genre motivators and carnival genres of demotivators, as well as the emergence of the profession of motivational speaker ("motivational speaker").

Motivational discourse texts have their own linguopragmatic characteristics. $n$ particular, the methodological ambiguity of the knowledge communicated by the creators of the texts of motivational discourse relies on their life experience and their outlook. Describing and constructing efficient behaviors, they often offer confirmation of the truth of personal observation, description own feelings and emotions, thoughts. Example: Although I have been using these principles for several years, just telling about them gets me excited all over again. I want all of you to get out of life what these truths are doing for me (M. Лi). In this case, the stylistically neutral first part of the first sentence differs from the emotionally saturated second part, in which expressive vocabulary in the form of colloquial expressions get excited and all over again demonstrates the specialist's attitude. The second part of the fragment conveys the individual experience of the author and his insistence on the subject at the linguistic level it is replicated again by the spoken vocabulary (get out of life, all of you) and the non-standard syntax characteristic of elliptical structures of informal communication.

In addition to imaginative vocabulary, a pronounced orientation to the addressee, numerous references to the personality of the reader or, conversely, to their own personal and personal experience, the authors of texts of motivational discourse in their works constantly refer to some scientific sources without specifying specific works, authors and theories. In most cases, such references seem to be explanations for beginners: In the early 1800's, when students of human behavior first began to realize that the mind was dual in its operation, the mind below the level of consciousness was named the subconscious mind. It is worth noting, however, that some authors provide bibliographic lists at the end of a chapter or book, but they do not necessarily contain all the sources cited in the text, and are often lists of publications for a more detailed study of the problem.

Authors of motivational literature use general scientific and, to a lesser extent, special terms, but try to convey their content in accessible form to the reader, resorting to comparisons and metaphors. One of the typological features of the genre is described in his article by 
K. Alekseev ${ }^{32}$. According to the researcher, the metaphor of psychological laws is widespread in the discourse of applied and popular psychology (psychological laws of management), while it is not used in modern scientific discourse, and psychologists are no longer talking about new knowledge in terms of law, but rather a mechanism. The metaphor of the law, according to the scientist, gives the discourse of popular psychology a hue of sci-fi, becoming another means of pervasive content. It is emphasized that classical science has strict rules and procedures for substantiation of knowledge, whereas in applied and especially popular psychology such rigor is absent. Indeed, the freedom of interpretation of theories, concepts and particular concepts is observed in many authors of this direction, and their passion for the colloquial and everyday way of thinking negates their created scientific approach to the issue and creates a peculiar stylistic contradiction - contradictions in the desire to present information together thus, in the simple for perception, the trivial form ${ }^{33}$.

In some cases, the authors place a glossary of terms and key concepts mentioned in the text at the end of the book. The presence of such a structural element brings the motivational literature closer to scientific, educational and scientific-cognitive, for which a glossary or a subject index is a compositionally significant component.

In order to convince the reader of a professional view of the problem, the authors of motivational texts often indicate in the book their titles and regalia. Name extension in the form of Ph.D. encourages the recipient of the information to perceive all of the facts and evidence as scientifically substantiated, and the author himself as an expert and scholar who has been recognized in academia. In some cases, Yu. Gilyasev points out, "such" reclamation "of status corresponds to reality, taking into account the Western tradition of self-presentation in society. However, sometimes the mention of merit and rank is clearly permissive. The author of the selfdevelopment guide, "Make Money Now," identifies himself as Dr. Joe Vitale, enhancing his credibility in the eyes of the reader. However, the publication does not mention that he is a doctor of metaphysics. In fact, this degree does not exist, and he was awarded a non-accredited educational institution ".

32 Алексеев К. И. Метафоры и их пресуппозиции: воздействие в научном дискурсе // Психологическое воздействие в межличностной и массовой коммуникации / отв. ред. А. Л. Журавлев, Н. Д. Павлова. Москва: Институт психологии РАН, 2014. С. 112-120.

33 Гилясев Ю. С. Прагматика англоязычного мотивационного дискурса // Ученые записки Петрозаводского государственного университета. 2017. № 5 (166). С. 70-76. 
Elements of artistic style at the level of lexical means can be distinguished without exception in all samples of texts of motivational discourse. The authors use different tropes and figures of language to move from the level of theoretical abstraction to the level of figurative fiction, for example: It will not be hard to let the sunshine of happiness show through (M. Лi). Such texts are often loaded with book vocabulary, for example:... the span of their illustrious careers, soporific, cast your mind back (B. Proctor). Often, especially in the phrase Most folks are lousy public speakers (D. Schwartz) - language expression is complemented by appreciation when the author seeks to express himself clearly and clearly, and to demonstrate his attitude. In such cases, imagery is already inferior to the place of rhetoric, so motivational discourse also acquires features of journalism.

Emotionality is the basic quality of journalistic style, which is expressed, as in the artistic style, through imaginative, stylisticallymarked words and syntactic collocations. However, in rhetoric and journalism, they actualize in the first place "the individual-author's attitude to the phenomena described, directly correlate with the implementation of the linguistic function of influence ${ }^{\prime 34}$.

The basis of all communication facilities motivational discourse is pragmatic conviction. The implementation of the linguistic function of the message is not peculiar to non-fiction texts in general; its existence can be regarded as a parameter that distinguishes the continuum of non-fiction texts from formalized functional varieties of language such as the intellectual and formal business styles in which it prevails function of realization.

At the same time, the emotionally-shaped component of the information being transmitted is manifested in the subordinate position with respect to the pragmatic dominant of the message. Interactions of imagination, the basic feature of the human psyche, the device performs the manipulation of consciousness, which is largely based on emotional and sensory images. According to A. Lipatov, there is an "inculcation" in the mind of certain ideas needed by manipulators ("motivators") ${ }^{35}$. However, unlike the political or other type of discourse, the authors of the texts of the motivational discourse see their purpose in changing the habits of thinking, attitudes and behavior with a positive effect for the recipients.

\footnotetext{
${ }^{34}$ Федоров В. В. Инвариантные языковые черты английской публицистики // Вестник КРАУНЦ. Гуманитарные науки. Петропавловск-Камчатский, 2014. № 2 (24). С. 19-31.

35 Липатов А. Т. Риторика в зеркале времени: Монография. Москва: ООО «Изд-во «ЭЛПИС», 2011.383 c.
} 
Thus, the process and result of communication at the present stage of the development of linguistics is viewed from the standpoint of a discursive approach, in which discourse is understood as a coherent text in combination with extralinguistic - pragmatic, sociocultural. psychological and other factors; the text, taken in the event aspect, which in turn allows us to distinguish different types of discourse, one of which is motivational discourse. The motivational discourse in this study is understood as the verbal interaction between the addressee and the addressee in order to have a positive influence on the emotional, volitional and activity sphere of the latter. The genres of motivational discourse are divided into oral (motivational speeches, sermons), written (motivational books) and creolized (so-called motivators and demotivators). The texts of the motivational discourse are characterized by a pragmatic instruction on the influence on the addressee, which determines the choice of certain linguistic means: tropes and figures of speech, book vocabulary, constructions of expressive syntax.

\section{CONCLUSIONS}

Persuasiveness is a communicative-speaking strategy aimed at rational persuasion and emotional influence on the addressee in order to induce him to take certain post-communicative actions. Persuasive communication is achieved through the use of different levels of persuasive means: logical (emphasis on a particular issue, concretization, simplification, polarization, intensification, etc.) and linguistic (linguistic, grammatical and stylistic linguistic means of persuasion). The purpose of persuasive communication is to convince and resolve differences between participants in the communication process by influencing one participant over another.

A communicative situation can be called persuasive if the author produces a statement that is intended to evoke a particular behavior of the recipient (or group of recipients) or influence his views. The basic linguopragmatic functions of persuasiveness include: influence by means of linguistic means on the addressee's consciousness, on his worldview, imagination; prompting him to take certain actions, changing the recipient's behavior in the right direction for the speaker.

In the study of persuasiveness we can talk about the cognitive aspect of its expression, which is realized through the knowledge and belief of the author, as well as communicative discursive, which includes the mental state of the author as a starting point and the process of persuasion. 
Persuasiveness is considered on the material of texts of motivational discourse, which is defined as verbal interaction of the addressee and the addressee in order to have a positive influence on the emotional, volitional and activity sphere of the latter. Motivational discourse is characterized by a variety of genres: oral (motivational speeches, sermons), written (motivational books) and creolized (so-called motivators and demotivators). One of its most characteristic features is a pragmatic attitude towards influencing the addressee, which determines the choice of certain linguistic means, that is, the means of creating persuasiveness.

\section{SUMMARY}

The article deals with the notion of persuasion in linguistics. Persuasion is defined as a communicative and speech strategy aimed at rational persuasion and emotional influence on the addressee in order to make them take certain post-communicative actions. The means used in the text to persuade are presented at all language levels: logical and linguo-stylistic.

The dominance of the persuasion strategy is characteristic for motivation discourse which is a verbal interaction between the addresser and the addressee the former trying to make a positive impact on the emotional, volitional and activity sphere of the latter. Motivation books belong to the written genre of motivation discourse and are characterized by the use of various means of persuasion.

\section{REFERENCES}

1. Борисова С. С. Персуазивные стратегии в аналитических жанрах медиатекста. Дисс. Орел, 2016. 250 с.

2. Инжечик А. А. Персуазивная функция языковых средств немецкого политического дискурса // Молодой ученый. 2016. № 9. С. $1270-1275$.

3. Шелестюк Е. В. Способы, типы, приемы и инструменты речевого воздействия // Классическое лингвистическое образование в современном мульти культурном пространстве: материалы междунар. науч. конф.: в 2 ч. Ч. 2. 2006. С. 153-164.

4. Дейк Т. А. ван. Язык. Познание. Коммуникация / пер. с англ.; сост. В. В. Петрова; под ред. В. И. Герасимова; вступ. ст. Ю. Н. Караулова, В. В. Петрова. Москва: Прогресс, 1989. 312 с.

5. Голоднов А. В. Риторический метадискурс: основания прагмалингвистического моделирования и социокультурной 
реализации (на материале современного немецкого языка). СанктПетербург: Астерион, 2011. 344 с.

6. Rank H. Persuasion analysis: A companion to composition. Park Forest: Counter-Propaganda Press, 1988. 160 p.

7. Харджиева Е.С. Персуазивность в детективно-следственном дискурсе (на материале романов Н. И. Леонова и А. В. Макеева). Дис. Ростов-на-Дону, 2016. 165 с.

8. Скрябіна В. Б. Персуазивні стратегії любовного дискурсу: комунікативно-прагматичний аспект (на матеріалі англійськомовної художньої прози ХХ століття). Дис. Київ, 2011. Автореферат. 20 с.

9. Шелестюк Е. В. Текстовые категории аргументативности, суггестивности и императивности как отражение способов речевого воздействия // Вестник Челябинского государственного университета (Серия «Филология. Искусствоведение»). 2008. Вып. 26. № 30 (131). C. $170-175$.

10. Баган М. Заперечення як засіб увиразнення персуазивних значень // Проблеми гуманітарних наук. 2011. № 28. С. 108-116.

11. Шинкарук В.Д. Модус i диктум у структурі речення. Дис. Київ, 2003. Автореферат. 31 с.

12. Клименская Е.А. Персуазивный потенциал нативной рекламы в интернет-издании Meduza // Конференция «Ломоносов 2018». URL: https://lomonosov-msu.ru/archive/Lomonosov_2018/data/ 13260/78100_uid2456

54_report.pdf.

13. Голоднов А. В. Лингвопрагматические особенности персуазивной коммуникации (на примере современой немецкоязычной рекламы). Дисс. Санкт-Петербург, 2003. Автореферат. 23 с.

14. Скрябіна В. Б. Персуазивний портрет перекладача // Науковий вісник кафедри Юнеско КНЛУ Серія Філологія. 2014. № 28. С. 59-64.

15. Борисова С. С. Персуазивные стратегии в аналитических жанрах медиатекста. Дисс. Орел, 2016. 250 с.

16. Харджиева Е. С. Персуазивность в детективно-следственном дискурсе (на материале романов Н. И. Леонова и А. В. Макеева). Дис. Ростов-на-Дону, 2016. 165 с.

17. Смирнова И. В. Использование языковых средств речевой манипуляции для реализации персуазивной стратегии в текстах программ испанских политических партий // Вестник Российского 
университета Дружбы народов. Серия: Вопросы образования. Языки и специальность. 2014. № 2. С. 78-84.

18. Правикова Л. В. Персуазивность как когнитивная стратегия в парламентском дискурсе // Филологические науки. Вопросы теории и практики. 2018. № 1(79). Ч. 2. С. 359-362.

19. Petty R. E., Cacioppo J. T. Communication and Persuasion. Central and Peripheral Routs to Attitude Change. New York: Springer, 1986. 262 p.

20. Лобода Ю. А. Відтворення експресивних засобів політичних промов українською мовою (на матеріалі публічних виступів політиків Великої Британії та США). Дис. Київ, 2011. Автореферат. $21 \mathrm{c}$.

21. Стецик Т. С. Система лінгвістичних засобів вираження персуазивності в політичному дискурсі. URL: https://naub.oa.edu.ua/ 2013/systema-linhvistychnyh-zasobiv-vyrazhennya-persuazyvnosti-vpolitychnomu-dyskursi/.

22. Лютянська Н. І. Відтворення ситуацій міжетнічної взаємодії у мас-медійних британських та американських дискурсивних практиках. Дис. Миколаїв, 2017. 219 с.

23. Лютянська Н. І. Відтворення ситуацій міжетнічної взаємодії у мас-медійних британських та американських дискурсивних практиках. Дис. Миколаїв, 2017. 219 с.

24. Славова Л. Л. Мовна особистість у сучасному американському та українському політичному дискурсі. Дис. Київ, 2015. Автореферат. 36 с.

25. Приходько Н. Ю. Феминистский дискурс мировых религий: статус женщины в буддийской традиции // Вестник ТГЭУ. Серия: Философия. 2009. № 4. С. 95-104.

26. Іванців О.В. Когнітивно-дискурсивні основи формування корпоративного іміджу (на матеріалі англійськомовних прес-релізів міжнародних косметичних компаній). Дис. Львів, 2015. 225 с.

27. Бацевич Ф. С. Основи комунікативної лінгвістики: 2-ге вид., доп. Київ: ВЦ «Академія», 2009. 376 с.

28. Арутюнова Н. Д. Дискурс // Лингвистический энциклопедический словарь. Москва: Советская энциклопедия, 1990. С. 137.

29. Климчук В. О. Мотиваційний дискурс особистості: на шляху до соціальної психології мотивації: монографія. Житомир: Вид-во ЖДУ ім. І. Франка, 2015. 290 с. 
30. Климчук В. О. Мотиваційний дискурс особистості в інтеракційному просторі. Дис. Київ, 2015. Автореферат. 20 с.

31. Подоляк Ж. И. К вопросу о выделении мотивационного дискурса // Электронный научно-практический журнал «Гуманитарные научные исследования». URL: http://human.snauka.ru/ 2016/05/14850.

32. Алексеев К. И. Метафоры и их пресуппозиции: воздействие в научном дискурсе // Психологическое воздействие в межличностной и массовой коммуникации / отв. ред. А. Л. Журавлев, Н. Д. Павлова. Москва: Институт психологии РАН, 2014. С. 112-120.

33. Гилясев Ю. С. Прагматика англоязычного мотивационного дискурса // Ученые записки Петрозаводского государственного университета. 2017. № 5 (166). С. 70-76.

34. Федоров В. В. Инвариантные языковые черты английской публицистики // Вестник КРАУНЦ. Гуманитарные науки. Петропавловск-Камчатский, 2014. № 2 (24). С. 19-31.

35. Липатов А. Т. Риторика в зеркале времени: Монография. Москва: ООО «Изд-во «ЭЛПИС», 2011. 383 с.

\section{Information about the author:} Melko Kh. B., Candidate of Philology, Associate Professor at Korunets Department of English and German Philology and Translation School of Translation Studies of Kyiv National Linguistic University 35, Boholiubova str., Sofiivska Borshchahivka, 08137, Ukraine 